\title{
CDISC SDTM Ophthalmic Exam Test Name Terminology
}

National Cancer Institute

\section{Source}

National Cancer Institute. CDISC SDTM Ophthalmic Exam Test Name Terminology. NCI

Thesaurus. Code C117742.

Terminology associated with the ophthalmic exam test names codelist of the Clinical

Data Interchange Standards Consortium (CDISC) Study Data Tabulation Model (SDT M). 